\title{
Multicultural Education in Barcelona
}

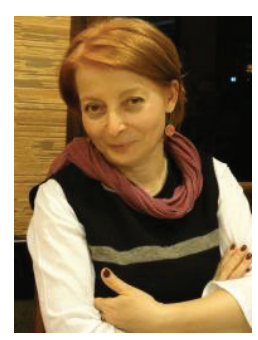

\section{Ümran TOPÇU}

İstanbul Bahcesehir University, Faculty of Architecture and Design

umran.topcu@arc.bau.edu.tr

\begin{abstract}
Multicultural Education is generally defined as any form of education incorporating different cultural backgrounds. Architectural education is inherently multidisciplinary and celebrates cultural diversity. In many cases, culture is defined in the broadest possible sense covering nationality, language, religion, class, gender etc. The main objective of multicultural education is to remove barriers for educational opportunities and promote success for students from different cultural backgrounds. This paper is about an international workshop held in Barcelona, June 2017, between Universitat Politecnica de Catalonia/Escola Tecnica Superior d'Arquitectura de Barcelona, Bahcesehir University Faculty of Architecture \& Design and Smt. K.L. Tiwari College of Architecture of Mumbai. The title of the workshop was "BCN Step by Step: Gaudi and his Time". Twenty-four students from three faculties worked in joint groups and were asked to create a stop motion video as the end product of the workshop. Growing popularity of videos for education proved to be right in the case of Summer Workshop 2017 of ETSAB, $B A U$ and Tiwari College. Thinking and reflecting on Gaudi's buildings, students had a chance of experimenting lived space by using all their senses. Sketches and mixed images made up their stop motion videos. Multicultural collaboration and diversity were the key factors of this group.
\end{abstract}

Keywords: Barcelona, multicultural education, workshop, stop motion video

\section{Barselona'da Çok Kültürlü Eğitim}

Öz: Çok Kültürlü Eğitim, genel olarak değişik kültürel arka planlart olan eğitimleri bir araya getirmeyi amaçlayan eğitim şekli olarak tanımlanır. Mimarlık eğitiminin özünde çok disiplinli olmak kadar çok kültürlü olmak da vardır. Kültür ise geniş bir tanımlama ile milliyet, dil, sınıf, ırk, cins vb. gibi alanları kapsar. Ĕgitim alanında amacı, sınırları kaldırmak ve değişik kültürel arka planlardan gelen ögrencilerin başarısını sağlamaktır. Bu makale, Haziran 2017'de Barselona'da gerçekleşmiş olan Uluslararası bir atölye çalışmasını anlatmaktadır. Katalonya Teknik Üniversitsi’nin Mimarlık Fakültesi (ETSAB), İstanbul Bahçeşehir Üniversitesi Mimarlı ve Tasarım Fakültesi ve Hindistan'dan Mumbai Tiwari College Mimarlık Bölümünden öğrencilerle gerçekleşmiştir. Atölye çalışmasının başlı̆̆ı "Adım Adım Barselona:Gaudi ve Zamanı"dır. Üç fakülteden 24 ögrenci karışık gruplar oluşturarak, 5-6 dakikalık "Stop Motion Videolar" hazırladılar. Videoların mimarlık eğitimi alanında giderek daha fazla kullanılır olduğu gerçeğinden hareketle, Workshop Final Projelerini bu şekilde hazırlamalarl istendi. Gaudi'nin işleri ve Barselona şehrinin geneli üzerinde, tüm duyularıla algıladıklarını videolarına yansıttılar. Videolardaki görüntüler öğrencilerin eskizlerinden ve diğer karışık görsellerden oluşmaktaydl. Çok kültürlü iş bölümü ve çeşitlilik halinin, tüm grupları bağlayan en önemli anahtar faktörler olduğu gözlemlenmiştir.

Anahtar Kelimeler: Barselona, Çok Kültürlü Eğitim, Atölye Çalışması, Stop Motion Video 


\section{INTRODUCTION}

Architectural education is inherently multidisciplinary and celebrates cultural diversity. We are presented with a great opportunity to embrace a phenomenon that is essentially human. Incorporating a variety of dimensions into architectural education programs honors the many ways in which locales, communities and cultures texture our life stories. Celebrating a multidimensional sense of place encourages recognition of the uniqueness of each individual's connections with the places that create the rich, meaningful context of our lives.

When a brief history of multicultural education is viewed, conceptualizations of multicultural education evolve and diversify. It becomes even more important to visit its historical foundation. How did the earliest form of multicultural education come about and what triggered it? How has multicultural education developed since its earliest conceptualizations?

Roots of multicultural education lie in the civil rights movements during 1960s in the USA. People who challenged discriminatory practices in public institutions carried out social action [1], [2]. As for the public institutions, educational institutions were targeted. They were the most oppressive and hostile to the ideals of equality. In the late 1960s and 1970s, the woman's rights movements forwarded the challenges for education reform. Women's rights groups challenged inequalities in all forms besides education. Feminist scholars and other women activists insisted on a curricula more inclusive of diverse histories and experiences. Educational institutions and organizations addressed concerns for traditional curriculums. The separate actions of various groups claiming dissatisfaction with the inequalities of the education system and the resulting reaction of institutions during the late 1960s and 1970s happened to be the earliest conceptualizations of multicultural education. James Banks, as a pioneer of multicultural education, was among the first multicultural education scholars to examine schools as social systems from a multicultural context [3]. His conceptualization was grounded on the idea of educational equality. According to Banks, a multicultural school environment examines and transforms school policies, teachers' attitudes, instructional materials, assessment methods, counselling and teaching styles.

Besides USA, the cultural landscape all over the western societies seemed to be missing to provide all students with creative and critical thinking skills, intercultural competence and social and global awareness. The education system was not good enough to prepare the students to completely participate in an increasingly diverse society. Towards the final decade of the twentieth century, multicultural education scholars refocused on developing new approaches and models of education and learning built on a foundation of social justice, critical thinking and equal opportunity. Educators, researchers and cultural theorists began to deconstruct traditional models both in lower and higher education arenas from a multicultural framework. Both schools and society were re-examined from a progressive and transformative framework. The emerging conceptualizations of multicultural education indicated that this work must be interpreted with social and political structures because they are linked and seem to be starting points in eliminating inequalities in the society. It is important to keep in mind that multicultural education is rather a new concept that will be changing to satisfy the needs of changing societies.

Multicultural education is a comprehensive reform in solving problems arising from cultural conflicts and to support students in developing empathy so as to recognize their mutual cultures and in doing so increase their academic success. Penny, Forney and Harlee [4] set out the following principles to follow in multicultural education; 
1. An essential part of multicultural education ought to be to allow different voices to be heard,

2. The verbal and nonverbal communication models of the teacher need to be analyzed continuously so as to raise the participation of students in their learning process,

3. Multicultural education should occupy a place in the formal educational program,

4. Multicultural education should encompass all levels,

5. Multicultural education should teach students to think critically so as to develop objective research and learning tools and allow them to ask questions freely,

6. Multicultural education necessitates an understanding of the family culture of that community,

7. Multicultural education should be evaluated as a source of benefit for the community

As the first principle points out, hearing of different voices has a primary importance in challenging diversities. Architectural education soon adopted itself to this reality. International and multinational workshops are held in architectural schools from different countries.

Architectural design education consists of theoretical and practical courses aiming at contribution to the development of the society at social and cultural levels besides the economic. With the advent of globalization another aim should be contribution to the society at the international level. In this context, besides formal architectural education, informal studies such as workshops have a growing importance. As Driscoll says [5], learning is a persisting change in human performance or performance potential that must come about as a result of the learner's experience and interaction with the world. As for a form of interaction, workshops are held frequently between two or more number of architectural schools from different countries resulting in outstanding success and sharing. They help the student to improve design thinking skills, learning by doing skills, creating motivation for creativity and most important of all, selfconfidence in international environments. 


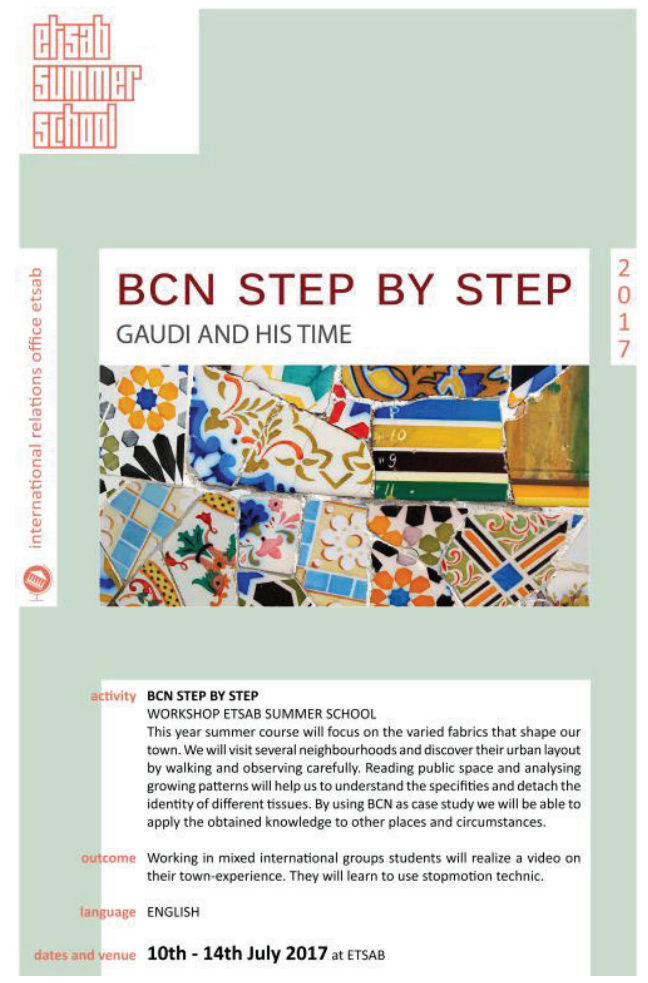

Image 1. Poster of the workshop

This paper is about a workshop titled "BCN Step by Step: GAUDI and his Time" held in Barcelona, on 1014 July, 2017 (Poster Image 1). It was held between Escola Tècnica Superior d'Arquitectura de Barcelona, BAU Faculty of Architecture and Design of İstanbul and Smt. K.L. Tiwari College of Architecture of Mumbai. 24 students from three schools worked in joint groups that consist of four members. As the assignment of the workshop, students were asked to create a stop motion video of the works of Gaudi they visited. Going through Gaudi's works in Barcelona and environs, Spanish, Turkish and Indian students encountered the various places in the city with all their senses and emotions. In spite of the short time, the students searched for a best learning experience (Image 2).
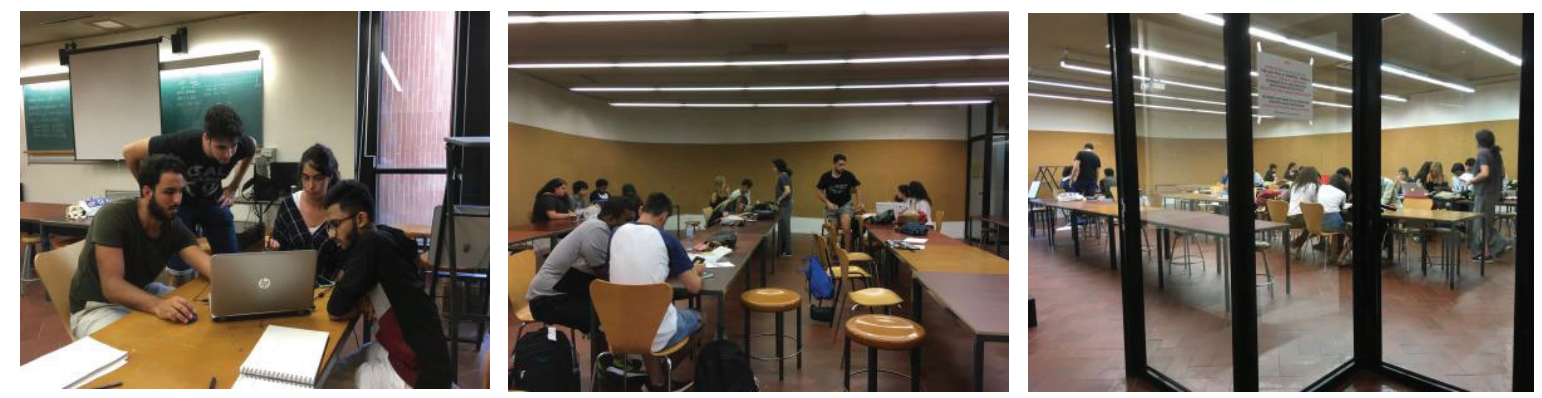

Image 2. Students at work in joint groups 
Presenting information is an important part of learning. Some presenters are verbalizers while some are imagers. Verbalizers are better in presenting the information in words and imagers in pictorial form [6]. So, if information is presented in both formats, the students can choose the best for their learning between the formats. Learning preference is a function of learner's capability of information intake. Here, intake means what the learner finds important or worth learning.

Videos are effective means of using the auditory and the visual perception for learning. When the video presents more information than the learner can intake, there might be a perceptual overload. We, human beings, are so good at processing the appropriate amount of information at a time. The overload in watching a video can be interpreted based on two theories: cognitive load theory and cognitive theory of multimedia learning [7]. These two theories both state that human memory has a certain cognitive capacity and if it is overloaded, learning may not be optimized. According to this, in order to learn more effectively, the cognitive load should be kept optimal. Since, people's perception capacity varies from one to another, the editorial decision for the optimal amount of information in videos for education is difficult. Videos are appealing. Nowadays, they can be produced with low budgets which is one of the important challenges for universities.

\section{METHODOLOGY}

In this workshop, the students were asked to create a stop motion video of their Barcelona and Gaudi experiences. They were supposed to focus on the spatial, visual and audio characteristics of the city through Gaudi's works. The student groups produced 6 videos. The duration of the video was defined between three to five minutes. The titles of the videos were: "Waves and Shapes", "Trenk Life", "Light of Gaudi", "3 Tourists \& 1 Local", "Gaudi Experts" and "Casa Mila". Since they were working against time, in the final presentation the students found themselves in a position of saying the most in 10 to15 minutes using appropriate amount of verbal and image information. The oral presentation of the final stop motion video took place on the last day of the workshop.

The students who participated in the workshop did not know each other before since they were from three different universities and also from different levels of architectural education. So they were all asked to present themselves to the class. After this, they were given a short time for getting into groups of four students. In our opinion, it was important that the students should themselves decide in which group they were going to take part. When all the groups were formed, they were asked to think about a name for their groups. After the groups were formed, it was time to introduce the stop motion technique to the workshop students. In general, this was not a commonly used representational tool at the three collaborating universities. The students were shown different examples and were informed about possibilities of new ideas for making the videos.

In image 3, there are three frames of the stop motion "Gaudi Experts". One can have a look at the city in three different ways: first, as monochromatic or without color, light or textures, second as more colorful and third as in the other color versions where everything gets mixed together. 

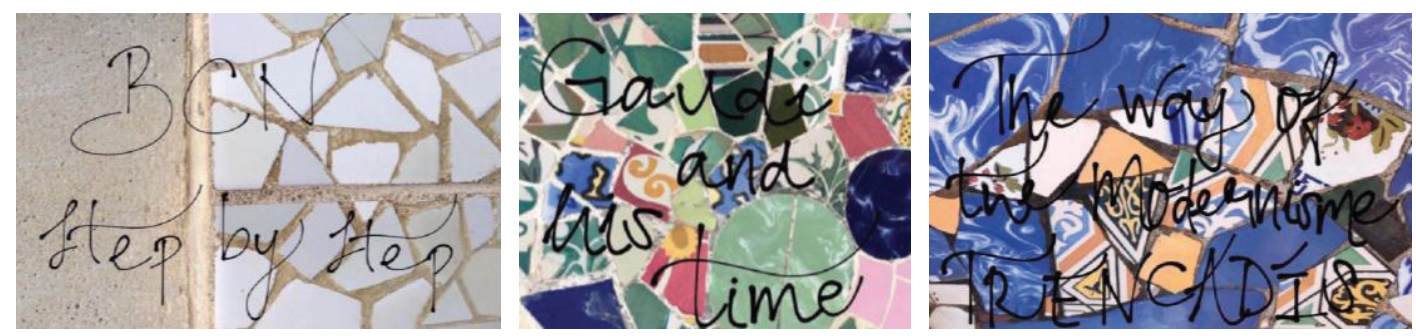

Image 3. Stop motion frames, "Trenk Life"

As seen in Image 4 and Image 5, two of the frames for two different stop motion videos titled "Waves and Shapes" and "Gaudi Experts", a similar technique of hand drawing and the real image are presented next to each other. This happens to be very common in stop motion videos.
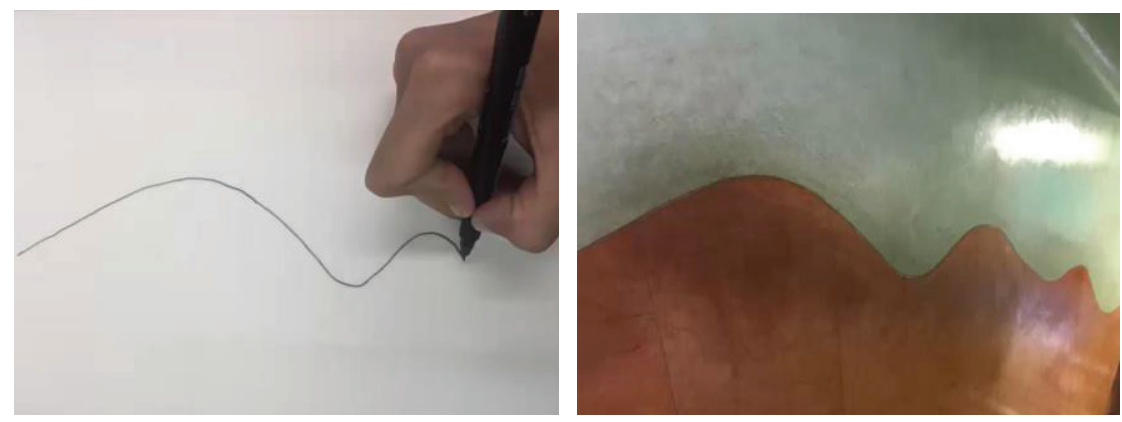

Image 4. Stop motion frames, "Waves and Shapes"
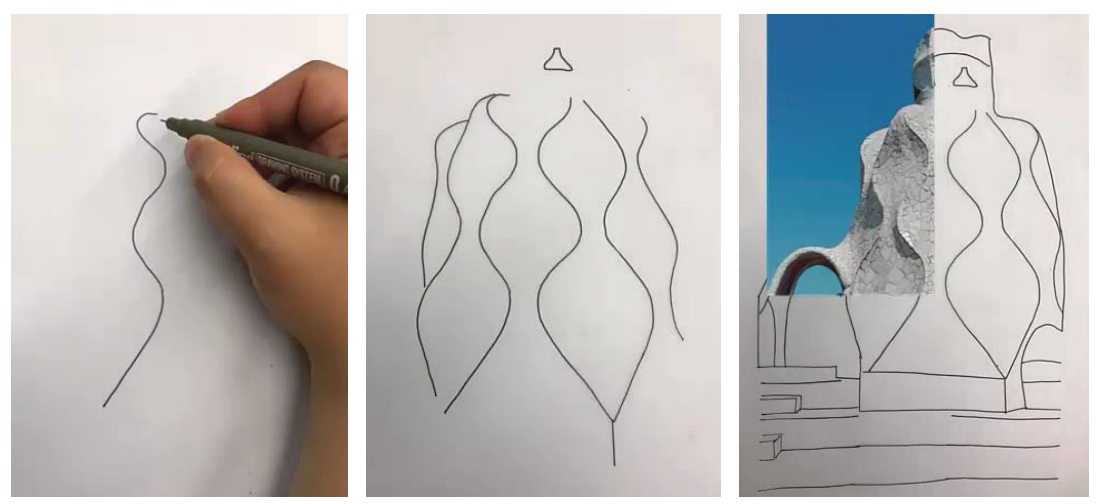

Image 5. Stop motion frames, "Shapes and Gaudi Experts"

One of the important stages of doing a stop motion video is the way the story is explained, namely the story board. The storyboard concept was defined as a tool for creating the videos. All of the elements that took part in the movie; scene, frames, space, camera position, music, movements, characters, time, action were explained in detail. The students were given a template storyboard to guide them to design the content of 
their group story. They had to hand this template in along with their drawings, at the final presentation of the stop motion videos, on the last day of the workshop.

On the template, the first box was supposed to have a three-dimensional drawing including the scene with the position of the characters and their movements. In the second box, they had to draw the plan of the scene with the position of the cameras and their movements around the space. And on the right side of the template they had to write the duration of the frame, the space where the action was going to take place, the music they were going to use, define the characters and explain all the relevant information for the video.
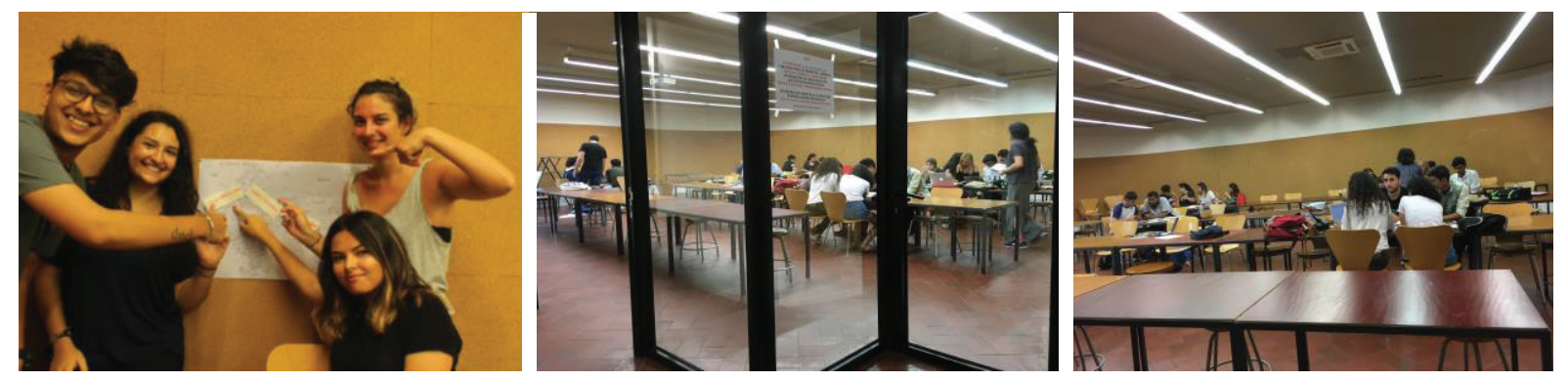

Image 6. Students working in joint groups.

In Image 6, the students are seen working in groups in this first stage, defining the total story and doing the first sketches of their storyboard. Once they had defined the storyboard the groups could start preparing all the documentation for the stop motion video. The students had to mix different techniques of graphic representation for doing their movies. One of the main rules was the importance of introducing hand drawings in their works. They did it using notebooks and pens, but also with digital tools.

The students could use different technological tools for doing their stop motion video. Each group decided which program they were going to use depending on their knowledge in computer applications. The tools that the students used for the stop motion videos were "Adobe Premier", "IMovie", "Windows Movie Maker" and "PowerPoint". It was not important for the instructors which platform the students used to perform the videos, because the software used was just a tool to explain the ideas of the different groups.

All of the students were encouraged to have a sketchbook along with them during the visits of the workshop. In general, at least one or two students per group were doing sketches while visiting the places and buildings. The students were asked to focus on hand drawings since it is a tool that coordinates the brain with the hand and allows capturing very quick impressions of the visited sites. As John Berger [8] said: "There are many types of drawings: ones that are studies, forms of research and other projects that are sketches of masterpieces". We were interested in these drawings as forms of research, as a tool for discovering new aspects of the cities. The students were not expected to do perfectly finished drawings as seen in Image 7. Incomplete ideas that appeared on the sketches were sought after. 

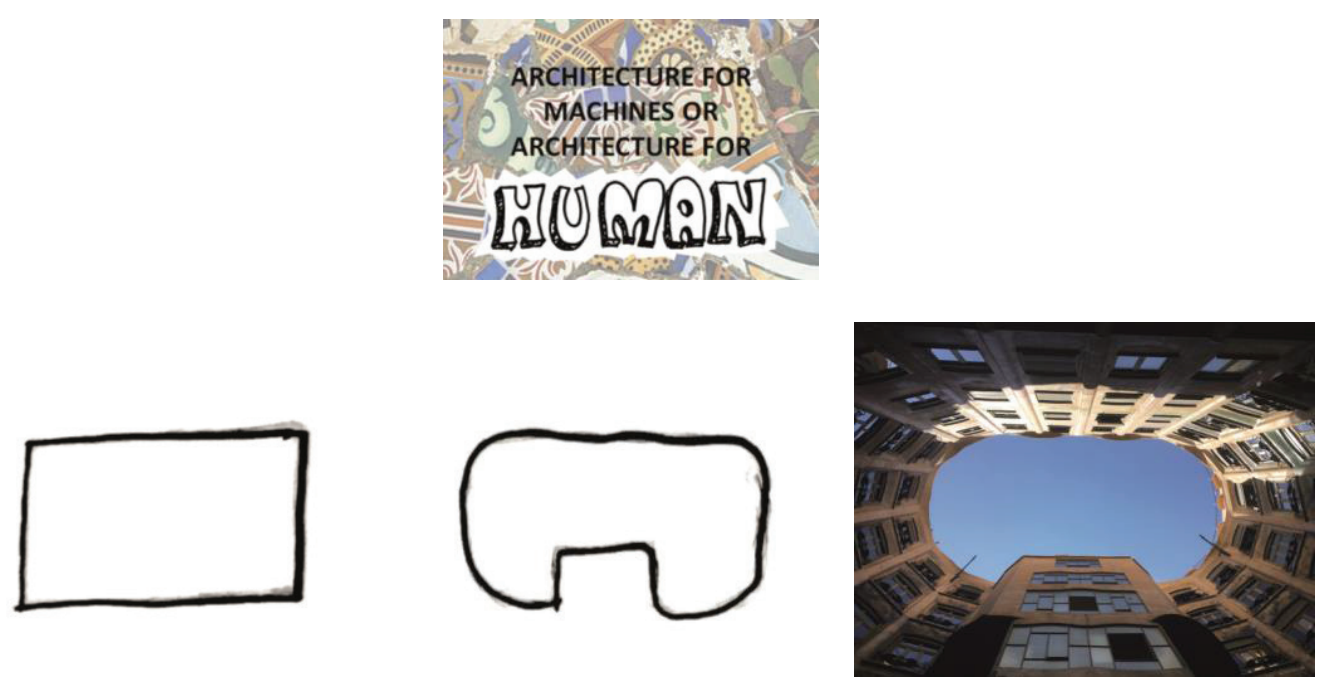

Image 7. Stop motion frames from "Shapes"

The focus was on the importance of exploring, studying and analyzing the city with Gaudi's works, as Georges Perec [9] described in his book "Our look moves around the space and gives us the illusion of relief and distance. So we built the image of space: from above and below, from left and right, from front and back, from close and a far". With the sense of vision and the sense of touch our students were able to find all the necessary information for creating their stop motion videos.

In image 8, we can see another example of mixing techniques. In this case, the group drew on some of the images of the stop motion, with the idea of defining and explaining the main important parts of the story they were explaining. Using trencadis of different mixed colors, the city parts were represented on a map. 

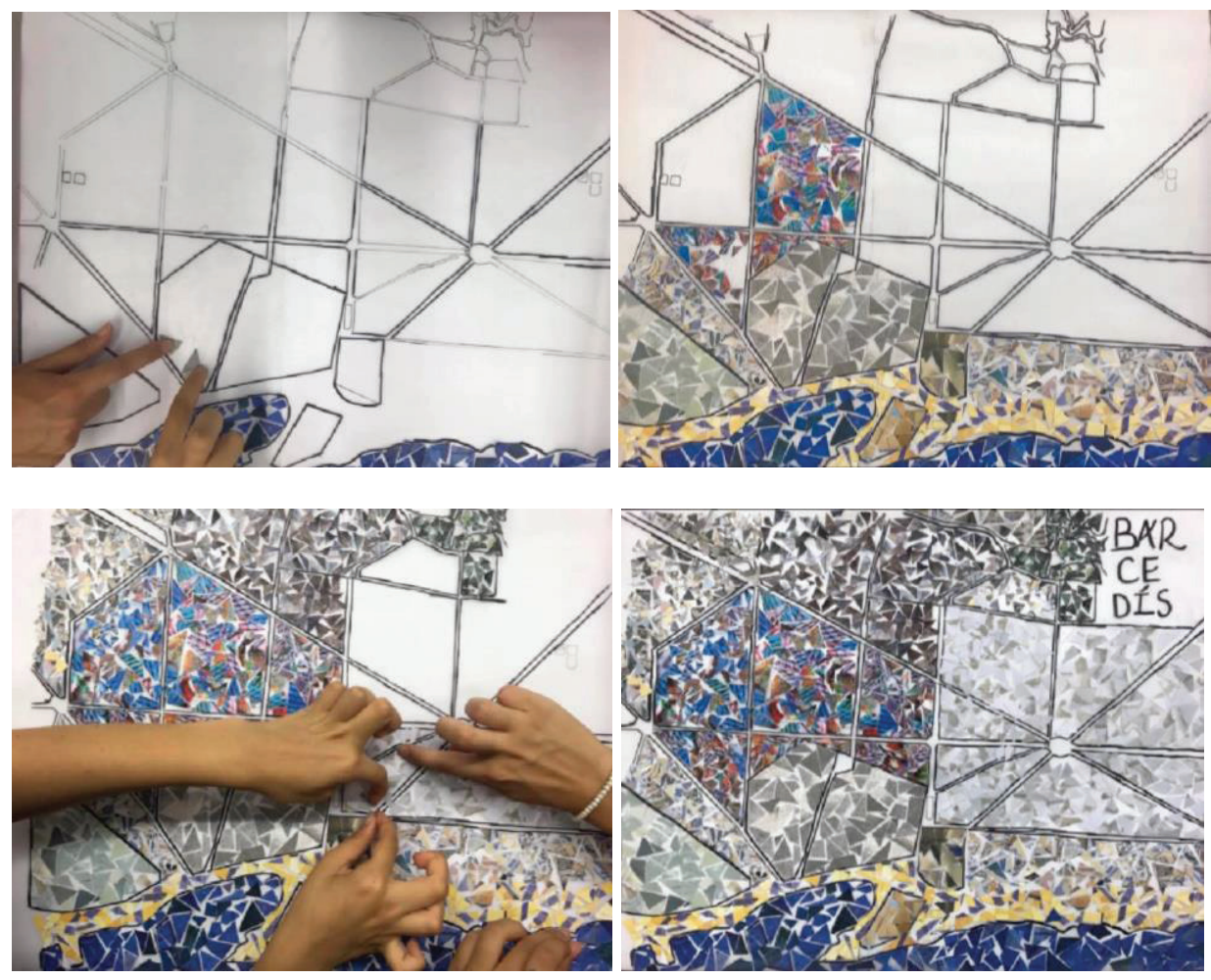

Image 8. Stop motion frames, "Trenk Life

Two different techniques of using newspaper letters and letters drawn on paper for doing titles, were used by different groups. This happens to be very common in stop motion videos (Image 9).
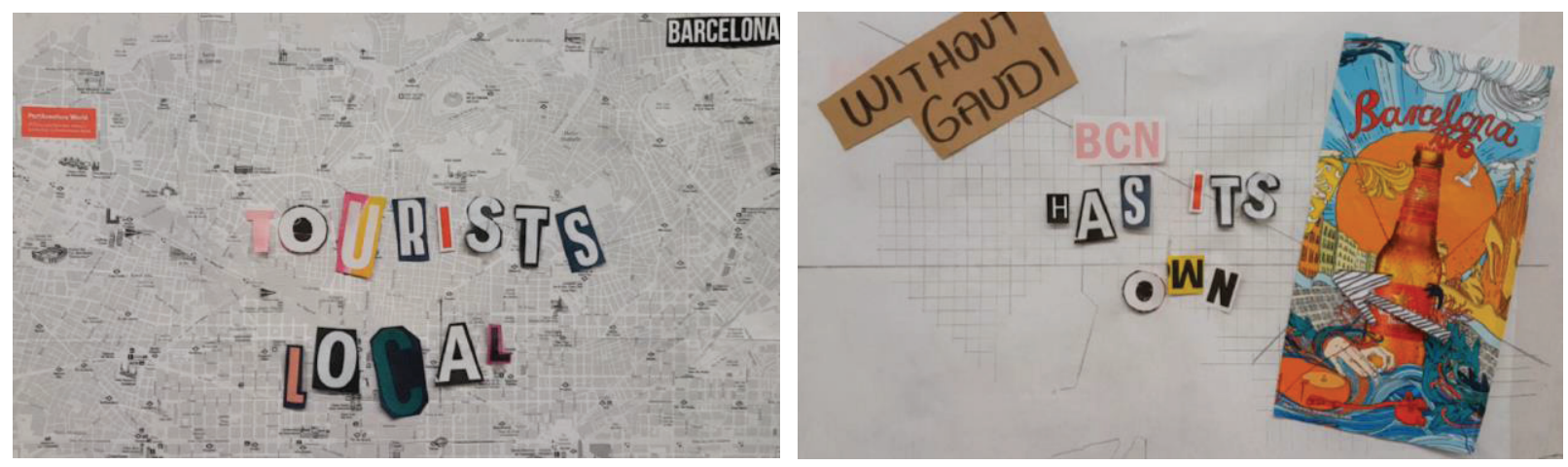

Image 9. Stop motion frames, "3 Tourists \&1 Local" 
All the groups used sketches and photographs in their stop motion videos. They were asked to create a story mixing all the techniques explained in the stop motion video. We explained the relevance of feeling with the cities. We encouraged the students not just to walk, but to live the places and buildings. As Pallasmaa [10] says "Architectural space is lived space rather than physical space, and lived space always transcends geometry and measurability". We challenged the groups for trying to find this lived space, these personal feelings they had while they were going around different works of Gaudi. Gaudi (Image10) has been very influential all through this workshop. In Image 11, there are seven frames of the stop motion video titled "Gaudi's Light". They defined their work, as a perceptual condition of mixed sensations. They played with light and color. They experienced the way light travelled through Gaudi's works. One cannot feel all these aspects only by using the sense of vision. It is important to give the students different tools and different ways of experiencing through architectural works.

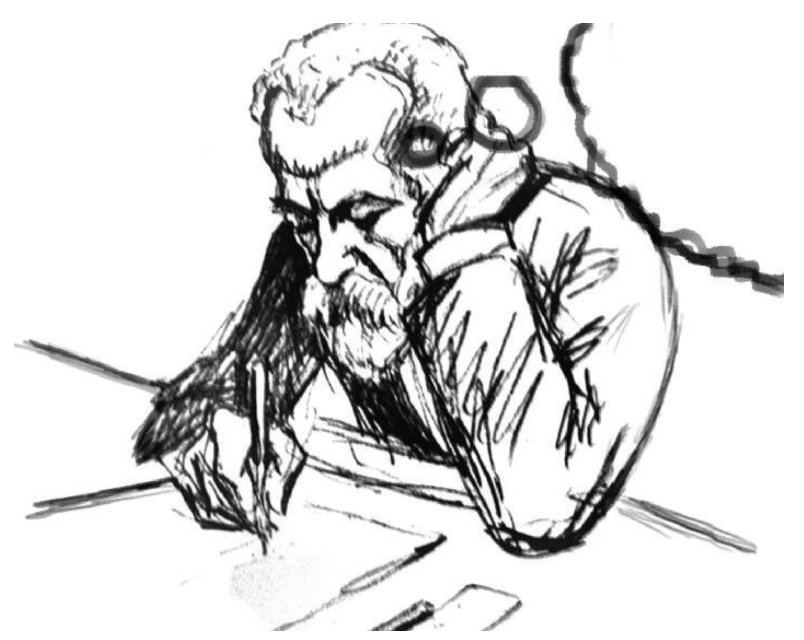

Image 10. "Gaudi from the students' sketching" 

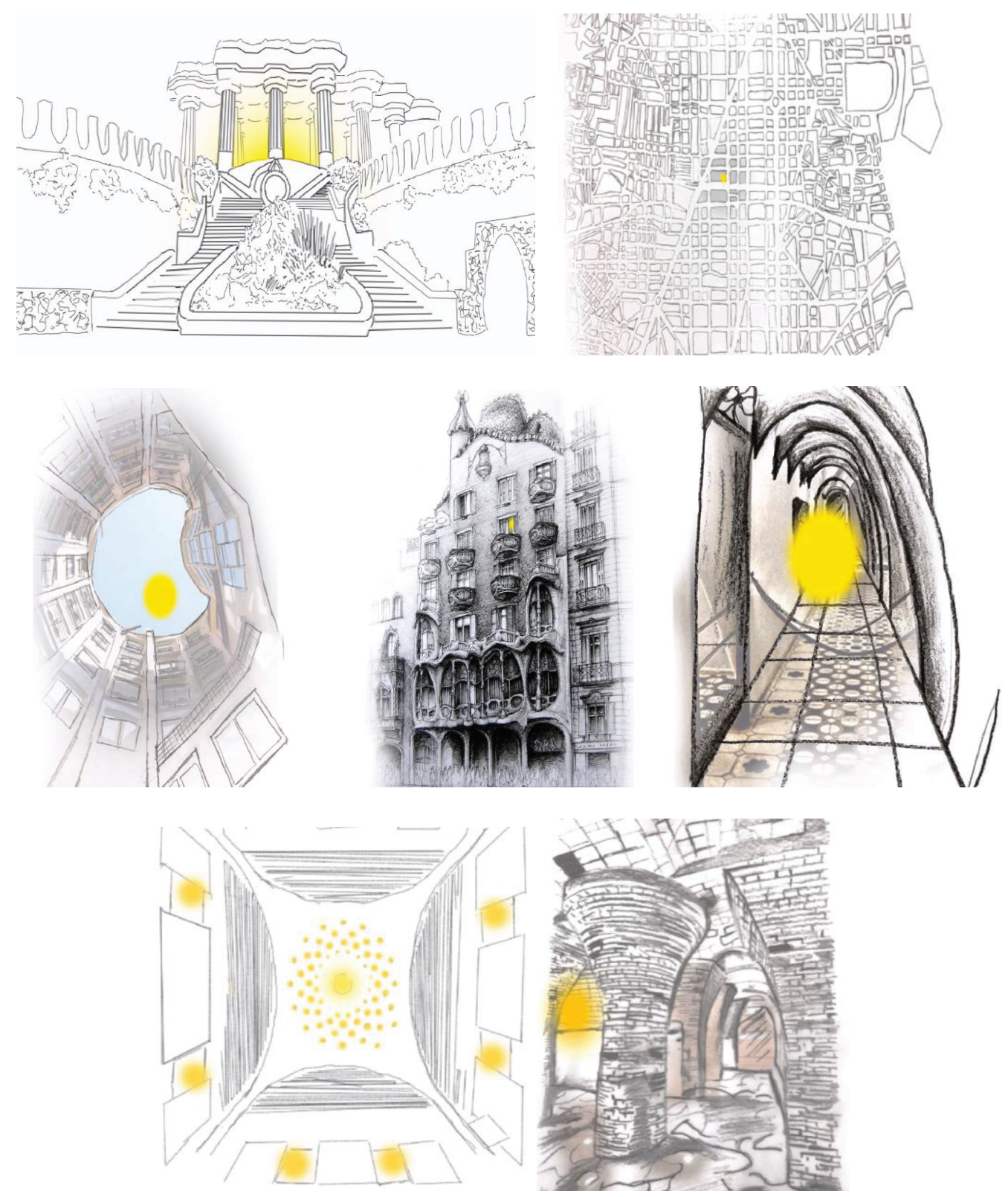

Image 11. Stop motion frames "Gaudi's Light"

In general, all the six videos presented on the last day of the workshop were related with Gaudi and his contributions to the city of Barcelona. All of the students did good research on this new way of experimenting with the city. It was a challenge for the students to work with a different tool of graphic representation of spaces, namely the stop motion video. All of them were very enthusiastic about this new experience and they succeeded. All the groups enjoyed thinking and imagining the best way to express their ideas through a stop motion video of a short duration. 


\section{CONCLUSIONS}

In recent years, videos have played an important role in education. Videos help create student engagement and facilitate learning. This is true for architectural design as well as learning in all design arenas. Over the last decades, technology has been reorganizing our ways of learning. With the advent of globalization, one of the aims of architectural design education has been contribution to the society not only at a national level but also at a multinational level.

International workshops held between architectural schools result in outstanding success and sharing because they incorporate different cultural backgrounds. Architectural education is inherently multidisciplinary and celebrates cultural diversity. In this respect, multicultural education should be evaluated as a source of benefit for the community.

Growing popularity of videos proved to be right in the case of 2017 Workshop in Barcelona. Potential benefits and challenges associated with making videos in the teaching and learning process at higher education level has been a good experience for the students and the faculty alike.

Thinking and reflecting on the buildings of Gaudi and places they visited, students had a chance of experimenting lived space by using all their senses and through their sketches and mixed images shown in their stop motion videos. It was a challenge because the conditions were not the best. Budget was zero and there was not much support neither in terms of producing, designing and technology. All students attending 2017 BCN Step by Step: Gaudi and his time Workshop stressed the importance of social and cultural development besides educational development. They also expressed the satisfaction of working with others in a multicultural environment. The organization that achieves these conditions is able to create an environment where all members can contribute their maximum potential and the "value in diversity" can be fully realized.

As a final word, increased diversity presents challenges to learners and teachers alike. Higher educational institutions must maximize the opportunities they offer and must transform from monolithic organizations to a multicultural model.

\section{REFERENCES}

[1] Banks, J., 1989. Multicultural Education: Characteristics and goals.

In J. Banks \& C. Banks (Eds.), Multicultural Education:Issues and Perspectives. Boston. Allyn \& Bacon.

[2] Davidman, L., \& Davidman, P., 1997. Teaching with a multicultural perspective: A practical guide. NY. Longman.

[3] Banks, J., 1981. Education in the 80s:Multiethnic Education. Washington DC. National Education Association.

[4] Penny C.M, Forney, A., \& Harlee, T.M., 2000. Issues challenging education. Preparing educators for multicultural classrooms. Retrieved from http:/www.horizon.unc.edu/projects/issues/papers/Penny.asp [5] Driscoll, M., 2000. Psychology of learning for instruction. Needham Heights, MA. Allyn \& Bacon [6] Mc Loughlin, C., 1999. The implications of the research literature on learning styles for the design of instructional material. Australian Journal of Educational Technology 15(3), pp.222-241

[7] Moreno, R., \& Mayer, R.E., 1999. Cognitive principles of multimedia learning: The role of modality and contiguity. Journal of Educational Psychology 99, pp.358-368

[8] Berger, J., 2007. Berger on Drawing. Occasional Press.

[9] Perec, G., 1974. Species of spaces and other pieces. Penguin Classics.

[10] Pallasmaa, J., 2009. The Thinking Hand:Embodied and Existential Wisdom in Architecture. John Wiley \& Sons. London 


\section{Ümran TOPÇU PhD, Associate Professor}

Ümran Topçu is a senior lecturer at the Faculty of Architecture and Design of Bahceşehir University. She got her Master's Degree from Istanbul State Academy of Fine Arts, Department of Higher Architecture (1977) and her PhD from Istanbul Technical University, Department of Urban and Regional Planning (2004).

Since 1997, Topcu teaches "Basic Design", "Architectural Design Studies", "People and Environment", "Urban Narratives" and "Masters \& PhD Courses". Topçu's areas of interest are "Architectural Design", "Architectural Education" and "Neighborhood \& Q.O.L".

Topcu has been coordinating International Summer and Winter Workshops between UPC ETSAB and BAU FA\&D, held in Barcelona and Istanbul since 2012. She has a special interest in reading, writing, sketching and travelling. In June 2019, she published the book titled "Barselona: Şehir/Mimarlık/ Gaudi" (NA1311. B3 T67 2019). 